Javier Ribera*, Mark Schubert, Siegfried Fink, Marco Cartabia and Francis W.M.R. Schwarze

\title{
Premature failure of utility poles in Switzerland and Germany related to wood decay basidiomycetes
}

DOI 10.1515/hf-2016-0134

Received August 26, 2016; accepted September 30, 2016; previously published online November 5, 2016

\begin{abstract}
In contact with soil, copper $(\mathrm{Cu})$ formulations as preservatives are expected to inhibit wood decay by fungi and other soil-borne microorganisms. However, $\mathrm{Cu}$ resistant brown-rot (BR) fungi lead to premature failures of utility poles at some sites. In this study, the service lives of 111 utility poles of Norway spruce (Picea abies (L.) H. Karst) (73 from Switzerland and 38 from Germany) impregnated with $\mathrm{Cu}$-based wood preservatives were investigated. Three segments of each utility pole were analyzed. The severity of decay was dependent on the preservative formulation. BR fungi and in particular Antrodia species were predominantly isolated from utility poles that were not treated with a co-biocide, e.g. boron (B). Cu-sensitivity of several isolated BR fungi was confirmed in studies on $\mathrm{Cu}$-amended medium and in Cu-treated wood. Isolates of Fibroporia vaillantii and Serpula himantioides showed a higher Cu-tolerance than the highly Cu-tolerant Empa isolate Rhodonia placenta (Empa 45) or Antrodia serialis.
\end{abstract}

Keywords: Antrodia serialis, Cu-based wood preservatives, Fibroporia vaillantii, field tests, Rhodonia placenta, Serpula himantioides, wood poles (WPs)

\footnotetext{
*Corresponding author: Javier Ribera, Empa, Swiss Federal Laboratories for Materials Science and Technology, Applied Wood Materials, Bio-engineered Wood, Lerchenfeldstrasse 5, CH-9014 St. Gallen, Switzerland; and Albert-Ludwigs-Universität Freiburg, Professur für Forstbotanik, Bertoldstrasse 17, D-79085 Freiburg i. Br., Germany, Phone: +4158 765 7607,

e-mail: javier.ribera@empa.ch
}

Mark Schubert and Marco Cartabia: Empa, Swiss Federal Laboratories for Materials Science and Technology, Applied Wood Materials, Bio-engineered Wood, Lerchenfeldstrasse 5, CH-9014 St. Gallen, Switzerland

Siegfried Fink: Albert-Ludwigs-Universität Freiburg, Professur für Forstbotanik, Bertoldstrasse 17, D-79085 Freiburg i. Br., Germany Francis W.M.R. Schwarze: Empa, Swiss Federal Laboratories for Materials Science and Technology, Applied Wood Materials, Bio-engineered Wood, Lerchenfeldstrasse 5, CH-9014 St. Gallen, Switzerland; and Albert-Ludwigs-Universität Freiburg, Professur für Forstbotanik, Bertoldstrasse 17, D-79085 Freiburg i. Br., Germany

\section{Introduction}

Wood has numerous ecological, biological, and economic advantages and is an important natural resource. Increasing demand for wood necessitates material saving, prolonged service life, and improved technologies of recycling. Wood products in soil contact (utility class 4) such as terraces, pergolas, stakes in vineyards, or utility poles, must be protected against microorganisms and insects (BS EN 460:1994). Cu-based preservatives are effective in this regard and have a low mammalian toxicity. Their fungicity is based on the sulfhydryl groups, which produce the coagulation of cytoplasmic proteins (Hughes and Poole 1989).

Approximately $800 \mathrm{M}$ utility wood poles (WPs) are currently in service in Europe. In Switzerland and Germany, 0.56 and 4.8 M WPs are in use, respectively, and 6.000-8.000 and 200.000-300.000 new WPs are installed in these countries annually. However, $1 \%$ (service life $<10$ years) of these replacements are due to premature failures. Thus, the total economic damage because of premature failure amounts to approx. $36 \mathrm{M} €$ per annum (Swisscom AG, BASF Wolman GmbH, pers. communication). In soil contact, brown-rot (BR) fungi are responsible for wood decay, and the mode of BR action in decay and the decay resistance in modified woods without biocides was reviewed by Ringman et al. (2014). BR biodeterioration is frequently tested in soil block tests also in the context of commercial Cu-type preservatives (Schultz and Nicholas 2012); see also soil block results of Little et al. (2010) and Janzen and Nicholas (2016). Accelerated field stake tests for rapid assessment of wood preservative systems were proposed by Schultz and Nicholas (2010). Freitag et al. (2011) tested up to 15 years long protection of borate-treated Douglas fir WPs in field tests and Häger et al. (2001) reported the results of 31-year-long exposure of Pinus sylvestris L. stakes treated with ammoniacal Cu-based preservatives. Nevertheless, results of long-time decay behavior of WPs are seldom reported in the literature.

Since 1968, the majority of WPs in Germany have traditionally been impregnated with $\mathrm{Cu}-\mathrm{Cr}$ (CC) by means of vacuum pressure processes. The recommended retention 
of CC for utility class 4 is $9 \mathrm{~kg} \mathrm{~m}^{-3}$ in Germany and $12 \mathrm{~kg} \mathrm{~m}^{-3}$ in Switzerland (Quitt 2014; Hach and Schwarze 2016). Nevertheless, these retentions do not completely protect wood against wood decay fungi. Several BR fungi have the ability to grow and survive at $\mathrm{Cu}^{2+}$ concentrations up to $1.6 \mathrm{mM}$ (Hughes 2004) or $100 \mathrm{mg} \mathrm{kg}^{-1}$ (Gadd 2007). Diverse mechanisms involved in the Cu-tolerance process have been described such as ability to absorb $\mathrm{Cu}$ into cell wall, extracellular chelation by metabolites, and intracellular complexion with metallothioneins (Young 1961; Cervantes and Gutierrez-Corona 1994; Civardi et al. 2015b; Kartal et al. 2015). For example, Wolfiporia cocos, Gloeophyllym trabeum, and Rhodonia placenta (Empa 45) can degrade wood treated with $\mathrm{Cu}$-based preservatives even at retention rates of $34.4 \mathrm{~kg} \mathrm{~m}^{-3}$ (De Groot and Woodwards 1999, Sierra-Alvarez 2007).

The number of premature failures of utility poles shows increasing tendencies (Bollmus et al. 2012) but there are only very few field studies examining the role of destroying fungi in these cases in Europe. In contrast, in North America, chromated-copper-arsenate (CCA) is still common for protection of utility poles (Bolin and Smith 2011) and thus problems in this regard are negligible (Freeman and McIntyre 2008).

The present study is dedicated to this problem, and 111 utility poles from Switzerland and Germany will be investigated in terms of the preservative formulation used and the service lives of the poles. Moreover, the type of fungal decay and the decay basidiomycetes should be identified. The copper sensitivity of the isolated strains will also be examined. As indicated above, long-term field decay results are seldom reported, and thus the expectation is that the result of the present paper will contribute to the practical evaluation of wood-protecting systems with service lives between 1 and 68 year.

\section{Materials and methods}

Distribution of the poles: A total number of 111 utility WPs of Norway spruce (Picea abies) were collected from various sites in Germany and Switzerland. The collection sites were selected from regions with pole stability problems. The segments were excised from each pole at ground level, at $30 \mathrm{~cm}$ above ground, and $30 \mathrm{~cm}$ below ground level (Figure 1a). The segments were immediately wrapped in kraft paper after marking for shipping to limit contamination during transport to the laboratory. The exact place where the WPs were collected can be requested from the research laboratory of the corresponding author.

Wood preservatives and decay types: Wood preservatives in treated WPs were identified according to Theden and Kottlors (1965) and AWPA (1999). Most WPs in Switzerland and all WPs in Germany were incised, i.e. penetration of preservatives was homogenously distributed in the sapwood (Figure 1b). Cu-based wood preservatives were qualitatively analyzed with a reagent containing $2 \%$ potassium ferrocyanide (Sigma-Aldrich, Buchs, Switzerland). The reagent induces a brownish color in $\mathrm{Cu}$-treated wood due to the reaction of $\mathrm{Cu}$ to copper hexacyanoferrate. The presence of boron (B) in the WP segments was observed after applying two different reagents: 1 . A solution of $20 \mathrm{ml}$ of $\mathrm{HCl}$ (Sigma-Aldrich) and $80 \mathrm{ml}$ of ethanol (Sigma-Aldrich) with $5 \mathrm{~g}$ of salicylic acid (Sigma-Aldrich) was applied to the wood surface. 2. After $5 \mathrm{~min}$, a $2^{\text {nd }}$ solution of $10 \mathrm{~g}$ of curcumin (SigmaAldrich) dissolved in $100 \mathrm{ml}$ of ethanol (Sigma-Aldrich) was sprayed onto the wood surface. After $40 \mathrm{~min}$, a reddish color was observed as a sign of positive reaction. Cr was determined by applying a solution of $1 \mathrm{~g}$ of diphenylcarbazide (Sigma-Aldrich) with $5 \mathrm{ml}$ of acetic acid (Sigma-Aldrich) and $15 \mathrm{ml}$ of ethanol 95\% (Sigma-Aldrich). This reagent induces a purple color in the presence of $\mathrm{Cr}$ (III). The wood decay type was determined by its typical appearance (Figure 2), e.g. cubical rot typical of BR and/or wood erosion from the surface, which

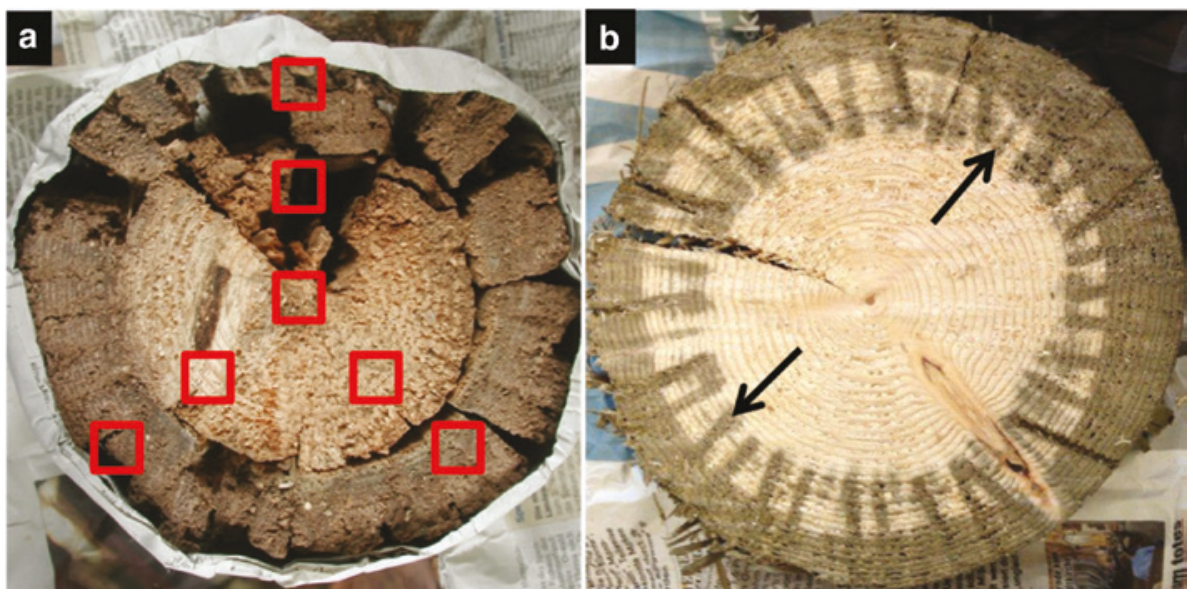

Figure 1: (a) Wood regions from which wood-destroying basidiomycetes were randomly isolated. (b) Cross section with numerous incisions (arrows). 


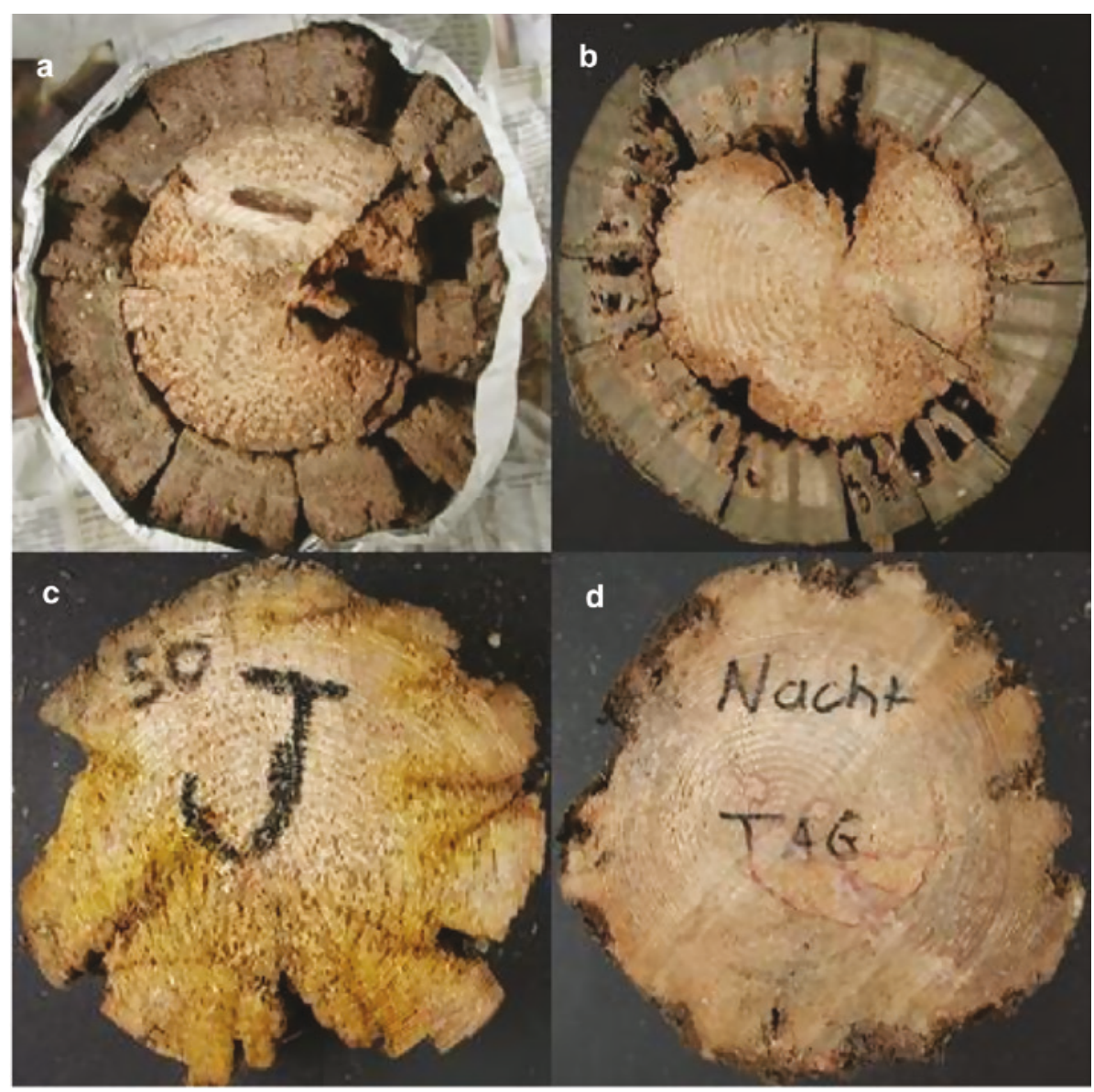

Figure 2: Damage of the selected poles by brown-rot (BR) $(a, b)$ and soft-rot (SR) $(c, d)$ fungi.

is typical of soft-rot (SR) (Schwarze 2007; Arantes et al. 2012; Arantes and Goodell 2014; Daniel 2014).

Wood decay basidiomycetes: For the isolation of wood decay basidiomycetes, seven increment cores were extracted aseptically from each WP segment and three smaller wood samples $(3 \times 3 \mathrm{~mm})$ from each core were placed into Petri dishes (Figure 1a) containing $20 \mathrm{ml}$ of 2\% Malt Extract Agar (MEA, OXOID, Pratteln, Switzerland) with $2 \mathrm{ml}$ of thiabendazole (Sigma-Aldrich) dissolved in lactic acid (Merck, Darmstadt, Germany), and then incubated at $22 \pm 1^{\circ} \mathrm{C}$ and $70 \%$ relative humidity $(\mathrm{RH})$ for 10 days. Thiabendazole-malt extract agar allows the growth of wood decay fungi but suppresses the growth of other fungi (Sieber 1995; Baum et al. 2003; Hopkins et al. 2005, Schwarze et al. 2012). Isolates were subcultured on Petri dishes containing $2 \%$ MEA and incubated at $22 \pm 1^{\circ} \mathrm{C}$ and $70 \% \mathrm{RH}$ in the dark. Isolates were identified microscopically (Stalpers 1978; Lombard and Chamuris 1990; Schmidt and Moreth 2003; Huckfeldt and Schmidt 2006). Additionally, the rDNA was extracted according to the protocol described in the kit "Extract N-Amp Plant PCR Kit" (Sigma Aldrich). In cases where the above kit did not extract the target rDNA, a second procedure described in "Fungi/Yeast Genomic DNA isolation Kit” (NorGen Biotek corp., Thorold, Canada) was used. The internal transcribed spacer (ITS1-5.8S-ITS4) of the extracted rDNA was amplified and sequenced for each strain. The primers for identification of the isolated fungi were designed according to the standard primers from White et al. (1990) (ITS1: 5'-TCCGTAGGTGAACCTGCGG-3' and
ITS4: 5'-TCCTCCGCTTATTGATATGC-3') and synthesized at Microsynth (Balgach, Switzerland). Amplification of the ITS region was achieved according to the polymerase chain reaction (PCR) protocol (White et al. 1990) with the following cycling parameters: Initial denaturation for $3 \mathrm{~min}$ at $94^{\circ} \mathrm{C}, 25$ cycles of annealing for $1 \mathrm{~min}$ at $94^{\circ} \mathrm{C}$, extension for $1 \mathrm{~min}$ at $48^{\circ} \mathrm{C}$, denaturation for $2 \mathrm{~min}$ at $72^{\circ} \mathrm{C}$, and final extension for $10 \mathrm{~min}$ at $72^{\circ} \mathrm{C}$. PCR products were sequenced and the obtained sequences were matched based on the basic local alignment search tool of National Centre for Biotechnology Information (NCBI).

Growth of BR fungi on $\mathrm{CuSO}_{4}$-amended MEA and decay evaluation: The Cu-sensitivity of each isolated basidiomycete species was evaluated with $\mathrm{CuSO}_{4}$ (Sigma-Aldrich). R. placenta (Empa 45) served as a positive control due to its known high Cu-tolerance (SierraAlvarez 2007; Civardi et al. 2015a). Petri dishes containing $20 \mathrm{ml}$ of $2 \% \mathrm{MEA}$ and a range of $\mathrm{CuSO}_{4}$ concentrations (0.000, 0.025, 0.050, $0.075,0.1,0.5$, and $1 \%$ ) were prepared according to Schmidt and Moreth (1996). All Petri dishes were inoculated centrally and incubated at $22( \pm 1)^{\circ} \mathrm{C}$ and $70 \% \mathrm{RH}$ for 10 days. Each fungal isolate was tested on five replicates per $\mathrm{Cu}$ concentration. The growth rate $(\mathrm{mm}$ day $^{-1}$ ) was determined by colony diameter measurements carried out along two perpendicular axes after $24 \mathrm{~h}$ (Schubert et al. 2008; Schwarze et al. 2012). Additionally, sapwood specimens of Scots pine $0.5 \times 0.5 \times 0.2 \mathrm{~cm}^{3}$ were vacuum-pressure impregnated with $\mathrm{CuSO}_{4}$ solutions $(0.00,0.025,0.050,0.075,0.1,0.5$, or $1 \%)$ according to 
EN 113 (1996). Before incubation, wood samples were sterilized with ethylene oxide (Sigma-Aldrich) and then placed onto $20 \mathrm{ml}$ of $2 \%$ MEA. Each fungal isolate was inoculated as described above. After 8 weeks, the wood specimens were removed, carefully cleaned with a brush, dried at room temperature for 2 weeks, oven dried $\left(103^{\circ} \mathrm{C}\right)$, and the mass loss (ML) was recorded.

Statistical analysis: Growth data were log-transformed and \%-data, such as the wood weight loss (WL), were arcsine-transformed prior to analysis of variance (ANOVA) and back-transformed to numerical values for presentation (expressed as mean \pm standard error). Means were separated using Dunett's test at significance levels of $\mathrm{P}<0.05$. The statistical package SPSS ${ }^{\circledR}$ (Version 22, SPSS Inc., Chicago, IL, USA) was adopted for this purpose.

\section{Results and discussion}

\section{Determination of wood preservatives and decay types in utility poles}

Important differences in the utility WPs from both countries are evident (Table 1). In Germany, the mean service life of WPs (9.6 year) was far lower than in Switzerland (32 year) (Table 1). A great diversity of wood preservative formulations was identified in WP segments from Switzerland (Table 1). Only 33\% of the analyzed segments from the WPs in Switzerland contained CC or Cu-Cr-B (CCB). The rest of the analyzed segments (77\%) contained a range of other preservative formulations. Around 90\% of the WPs impregnated with wood preservative formulations other than CC or CCB were installed before 1990. CC or CCB were identified in all WPs from Germany and all of them were installed after 1990. Expectedly, the different formulations were applied in the last $50 \mathrm{y}$. During this period, about 1500 wood preservative formulations were available on the German market (Mai and Militz 2007).

Table 1: Analysis of removed utility wood poles (WPs).

\begin{tabular}{|c|c|c|}
\hline Parameter & Germany & Switzerland \\
\hline Number of poles $(n)$ & 38 & 73 \\
\hline Range of service life (y) & $1-22$ & $7-68$ \\
\hline Mean service life (y) & 9.6 & 32 \\
\hline Identified preserv.: CC (\%) & 87 & 16 \\
\hline Identified preserv.: CCB (\%) & 13 & 17 \\
\hline Other preservatives ${ }^{\mathrm{a}}(\%)$ & 0 & 67 \\
\hline \multirow[t]{2}{*}{ Main decay type (\%) } & $\mathrm{BR}$ & SR \\
\hline & 98.5 & 63 \\
\hline BR fungi isolations (\%) & 45 & 10 \\
\hline
\end{tabular}

aOthers: Pole segments without CC or CCB, e.g. CCF (fluorine) or CCA (arsenic). BR, Brown-rot; SR, soft-rot.
In the 1990s, the EU started to regulate active ingredients against wood decay organisms in order to guarantee a low impact on human beings and the environment. Hence, the use of some compositions was restricted (BS 335-1 1992; European directive 98/8/EG 1998).

In Germany, the susceptibility of WPs for BR colonization was higher than in Switzerland (Table 1). Around 98\% of the WPs showed symptoms of BR decay, which were all treated with CC or CCB. In contrast, in Switzerland, mainly SR decay was detected in $63 \%$ of the segments and only three of them were impregnated with CC or CCB. Moreover, $92 \%$ of the WPs decayed by SR were installed before the 1990s and strong decay was not detectable. Accordingly, the WP susceptibility to BR fungi is strongly related to the application of recent wood preservative formulations without an effective co-biocide and only with a weak fixation of $\mathrm{Cu}$ in the wood (Humar et al. 2007). The finding in the present paper confirms the early observations of Leithoff et al. (1995), who demonstrated in a choice test the preference of Antrodia spp. for Cu-treated wood in combination with different amended media. As shown earlier, Cu-based salts are effective for protecting wood in soil contact against SR fungi, but are less effective against BR fungi (Woodward and De Groot 1999; Green and Clausen 2003; Freeman and McIntyre 2008).

Although the heaviest damage by BR fungi was observed at ground level, in some cases the damage had also spread above and below ground level. Twenty and 58\% of the WPs from Switzerland and Germany, respectively, had decay below ground level. The decay observed above ground level was similar in both countries (9 and 13\% in Switzerland and Germany, respectively). Various factors may explain the activity of BR fungi at ground level. For instance, the moisture content in the first layers of the soil maintains the wood above 30\%, which is optimal for BR decay (Palfreyman and Bruce 1994; Kües et al. 2007). Additionally, elevated preservative leaching has been related to the soil composition due to the affinity of the organic soil constituents to bound preservative compounds and the solubilization of metals $\mathrm{Cu}$ and $\mathrm{Cr}$ ) at low $\mathrm{pH}$ in soils due to the high content of organic acids (Freeman and McIntyre 2008).

\section{Isolation and identification of wood decay basidiomycetes}

In the present study, the total isolation ratio of BR fungi from WPs (45 and 10\% in Germany and Switzerland, respectively) was comparable to that in previous studies (seven up to 60\%) (Eslyn 1970; Zabel et al. 1985; Bollmus et al. 2012). Although almost 7000 isolations were made, it 
was impossible to isolate all BR fungi present in the wood due to contamination by other fungi from the environment that were able to rapidly colonize the substrate, e.g. Trichoderma spp., Penicillium spp., and Mucor spp. For this reason, the presence of other BR fungi in the WPs cannot be completely excluded, as described by Pfeffer et al. (2012).

Fungi were differentiated based on macro- and micromorphological features, such as clamp morphology, hyphal diameter, presence of hyphal strands, or color and odor of the mycelium (Nobles 1965; Stalpers 1978; Lombard and Chamuris 1990; Schmidt and Moreth 2003; Huckfeldt and Schmidt 2006). Such keys are useful for fungi identification, but nevertheless, confusions, doubts, or misidentification may occur at species level (Schimdt and Kebernik 1989; Palfreyman and Bruce 1994). Therefore, in the present study, all isolates were additionally identified by molecular biological methods.

The main wood decay basidiomycete was identified as Antrodia serialis, which was present on 32 and $75 \%$ of WPs from Germany and Switzerland, respectively (Table 2). Fibroporia vaillantii was isolated from $23 \%$ of the WPs, Serpula himantioides was the third most-abundant isolated fungus (18\%), and Sistotrema brinkmannii was isolated twice from poles in Germany. The other species were isolated only once from the WP segments in both countries (Table 2). All identified wood decay basidiomycetes have been reported previously in association with decay of wood products (Duncan and Lombard 1965; Wilcox and Dietz 1997).

\section{Growth of BR fungi on $\mathrm{CuSO}_{4}$-amended MEA. Decay evaluation of $\mathrm{CuSO}_{4}$-impregnated specimens}

The suppressive effect of $\mathrm{Cu}$-amended medium was higher for $A$. serialis than formerly reported by Civardi et al. (2015a) (Figure 3a). Statistical analysis revealed that the

Table 2: Brown-rot (BR) fungi isolated from utility poles.

\begin{tabular}{lrr}
\hline & \multicolumn{2}{c}{ Abundancy (\%) in } \\
\cline { 2 - 3 } BR fungi & Germany & Switerland \\
\hline Antrodia serialis & 31.8 & 75 \\
Serpula himantioides & 18.2 & - \\
Sistotrema brinkmannii & 9.2 & - \\
Fibroporia vaillantii & 22.8 & - \\
Gloeophyllum sepiarium & 4.5 & - \\
Tapinella panuoides & 4.5 & - \\
Postia dissecta & 4.5 & 12.5 \\
Neolentinus lepideus & 4.5 & 12.5 \\
Unknown fungi & - & \\
\hline
\end{tabular}
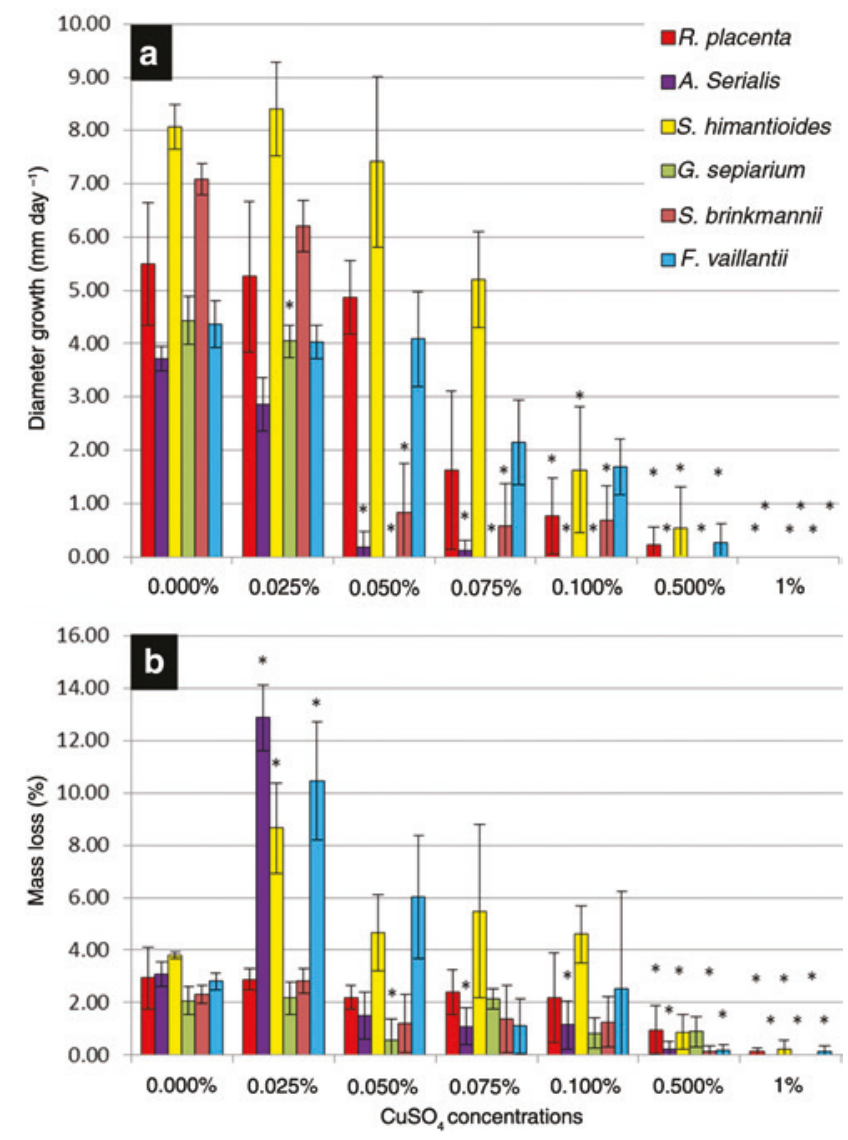

Figure 3: (a) Diameter growth of brown-rot (BR) isolates in MEA amended with different concentrations of $\mathrm{CuSO}_{4}$. (b) Mass loss (ML) by $B R$ isolates in Scots pine wood blocks treated with different concentrations of $\mathrm{CuSO}_{4}$ * ${ }^{*}$ Indicates statistical differences in comparison with controls; * $=\mathrm{P}<0.05$ (Dunnett's t-test two-way).

effect of $\mathrm{CuSO}_{4}$ varied among fungal species, a finding which is in good agreement with that of Schmidt and Moreth (1996). S. himantioides and F. vaillantii showed the highest tolerance to $\mathrm{Cu}$-amended medium (Figure 3a). A significant negative effect for $\mathrm{Cu}$-amended medium $(\mathrm{P}<0.05)$ was recorded in comparison with the controls for all wood decay basidiomycetes at concentrations higher than $0.075 \% \mathrm{CuSO}_{4}$ (Figure 3a). Interestingly, the highly Cu-tolerant strain $R$. placenta (Empa 45) was less tolerant than one isolate of $S$. himantioides.

MLs caused by basidiomycetes on Cu-impregnated wood are presented in Figure 3b. Low concentrations of $\mathrm{Cu}$ in impregnated wood $\left(0.025 \% \mathrm{CuSO}_{4}\right)$ resulted in a significant increase of ML by A. serialis, F. vaillantii, and S. himantioides $(\mathrm{P}<0.05)$. Collet $(1992)$ and Leithoff et al. 1995 demonstrated a similar stimulus for different isolates of $F$. vaillantii, when adding low $\mathrm{Cu}$ concentrations to the substrate. In comparison with controls, $\mathrm{CuSO}_{4}$ concentrations higher than $0.1 \%$ had an adverse effect on ML 
(Figure 3b), which was already reported by Schmidt and Moreth (1996), who found a high Cu-sensitivity for the basidiomycetes (A. serialis, R. placenta, F. vaillantii, $S$. himantioides). The highly Cu-tolerant fungus $R$. placenta Empa 45 and S. himantioides were tolerant to all $\mathrm{CuSO}_{4}$ concentrations, whereas S. brinkmannii and Gloeophyllum sepiarium were highly susceptible to all $\mathrm{CuSO}_{4}$ concentrations higher than $0.05 \%$ (Figure 3b).

\section{Conclusions}

Wood decay basidiomycetes associated with premature failure of utility WPs in Switzerland and Germany belong mainly to Antrodia spp. A direct correlation between fungal species and geographic regions was not evident but there is strong evidence that the type of wood preservative formulation has the highest selective pressure on BR fungal colonization and wood decomposition. In the absence of a co-biocide, WPs treated with CC formulations are highly susceptible to premature failures. The isolated BR fungi show significant differences concerning the Cu-resistance. A. serialis was the main wood decay basidiomycete isolated from WPs in both countries but the bioassays revealed that $A$. serialis is not highly tolerant to $\mathrm{Cu}$ concentrations. The isolates of $S$. himantioides and F. vaillantii demonstrated a greater $\mathrm{Cu}$-tolerance threshold and thus they might play an important role in removal of $\mathrm{Cu}$ from treated wood. Further studies are currently in progress, in which the Cu-sensitivity of the isolated wood decay fungi on wood treated with a range of commercial $\mathrm{Cu}$-based formulations and retentions are evaluated. Data about the locations where the WPs were sampled can be given by the corresponding author upon request.

Acknowledgments: The authors are pleased to acknowledge the financial support by the CTI (Kommission für Technologie und Innovation Project No. 17001.1 PFLS-LS). We thank Deutsche Telekom AG, Swisscom AG, and BASF Wolman for assisting in the preparation of wood poles and for the technical support.

\section{References}

Arantes, V., Jellison J., Goodell, B. (2012) Peculiarities of brown rot fungi and the biochemical Fenton reaction with regard to their potential as a model for bioprocessing biomass. App. Microbiol. Biotechnol. 94:323-338.

Arantes, V., Goodell, B. (2014) Current understanding of brown rot fungal biodegradation mechanisms: a review. In: Deterioration and Protection of Sustainable Biomaterials. Eds. Schultz, T.P., Goodell, B., Nicholas, D.D. ACS Publication, USA. pp. 3-21.

AWPA. (1999) American Wood Preservers' Association Book of Standards. American Wood Preservers' Association, Grandbury, TX, USA.

Baum, S., Sieber, T.N., Schwarze, F.W.M.R., Fink, S. (2003) Latent infections of Fomes fomentarius in the xylem of European beech (Fagus sylvatica). Mycol. Prog. 2:141-148.

Bolin, C.A., Smith S.T. (2011) Life cycle assessment of pentachlorophenol-treated wooden poles with comparisons to steel and concrete utility poles. Renew. Sust. Energy Rev. 15:2475-2486.

Bollmus, S., Rangno, N., Militz, H., Gellerich, A. (2012) Analyses of premature failure of utility poles. International Research Group on Wood Protection, p. 9. IRG/WP12-40584.

Cervantes, C., Gutierrez-Corona, F. (1994) Copper resistance mechanisms in bacteria and fungi. FEMS Microbiol. Rev. 14:121-138.

Civardi, C., Schubert, M., Fey, A., Wick, P., Schwarze, F. (2015a) Micronized copper wood preservatives: efficacy of ion, nano and bulk copper against the brown rot fungus Rhodonia placenta. PLoS One 10:e0142578.

Civardi, C., Schwarze, F., Wick, P. (2015b) Micronized copper wood preservatives: An efficiency and potential health risk assessment for copper-based nanoparticles. Environ. Pollut. 200:126-132.

Collet, O. (1992) Comparative tolerance of the brown rot fungus Antrodia vaillantii (DC.:Fr) Ryv. Isolates to copper. Holzforschung 46:293-298.

Daniel, G. (2014) Fungal and bacterial biodegradation: white rots, brown rots, soft rots and bacteria. In: Deterioration and Protection of Sustainable Biomaterials. Eds. Schultz, T.P., Goodell, B., Nicholas, D.D. ACS Publication, USA. pp. 23-58.

De Groot, R.C., Woodwards, B. (1999) Using copper-tolerant fungi to biodegrade wood treated with copper-based preservatives. Int. Biodeterior. Biodegrad. 44:17-27.

Duncan, C.G., Lombard, E.F. (1965) Fungi associated with principal decays in wood products in the United States. USDA Forest Serv., Forest Prod. Lab. Report No. WO-4. Madison, WI.

EN 113 (1996) Wood preservatives - test method for determining the protective effectiveness against wood destroying basidiomycetes: determination of toxic values. European Committee for Standardization (CEN), Brussels, Belgium.

EN 335-1 (1992) Hazard classes of wood and wood-based products against biological attack. Classification of hazard classes. British Standard Institution (BSI), London, United Kingdom.

EN 460 (1994) Durability of wood and wood-based products. Natural durability of solid wood. Guide to the durability requirements for wood to be used in hazard classes. British Standard Institution (BSI), London, United Kingdom.

Eslyn, W.E. (1970) Utility pole decay. Part II: basidiomycetes associated with decay in poles. Wood Sci. Tech. 4:97-103.

European Directive 98/8/EG (1998). Directive 98/8/EC of the European Parliament and of the Council of 16 February 1998 concerning the placing of biocidal products on the market. Official Journal of the European Communities. L123:1-63.

Freeman, M., McIntyre, C. (2008) A comprehensive review of copperbased wood preservatives with a focus on new micronized or dispersed copper systems. Forest Prod. J. 58:6-27.

Freitag, C., Morrell, J.J., Love, C.S. (2011) Long-term performance of fused borate rods for limiting internal decay in Douglas-fir utility poles. Holzforschung 65:429-434. 
Gadd, G.M. (2007) Fungi and industrial pollutants. In: Environmental and Microbial Relationships, Vol. IV. Eds. Kubicek, C.P., Druzhinina, I.S. Springer-Verlag, Berlin-Heidelberg. pp. 69-84.

Green, F., Clausen, C.A. (2003) Copper tolerance of brown rot fungi: time course of oxalic acid production. Int. Biodeterior. Biodegrad. 51:145-149.

Hach A., Schwarze F.W.M.R. (2016) Schweizerisches Holzschutzmittelverzeichnis. Bundesamt für Umwelt (BAFU). Bern, Switzerland. pp. 124-125.

Häger, B., Johnson, G.C., Thornton, J.D., Gardner, W.D. (2001) The Condition, after 31 Years Exposure, of Pine Stakes Treated with Ammoniacal Copper-Based Preservatives. Holzforschung 55:163-170.

Hopkins, A.J.M., Harrison, K.S., Grove, S.J., Wardlaw, T.J., Mohammed, C.L. (2005) Wood-decay fungi and saproxylic beetles associated with living Eucalyptus oblique trees: early results from studies at the Warra LTER site, Tasmania. Tas. Forest. 16:111-126.

Huckfeldt, T., Schmidt, O. (2006) Identification key for European strand-forming house-rot fungi. Mycologist 20:42-56.

Hughes, A. (2004) The tools at our disposal. Final Workshop COST Action E22 "Environmental optimization of Wood Protection", 22nd and 23rd March 2004; Lisboa, Portugal. p. 11.

Hughes, M.N., Poole, R. K. (1989) Metals and Micro-organisms. Chapman \& Hall Mehta, London.

Humar, M., Zlindra, D., Pohleven, F. (2007) Improvement of fungicidal properties and copper fixation of copper-ethanolamine wood preservatives using octanoic acid and boron compounds. Holz Roh Werkst. 65:17-21.

Janzen, S., Nicholas, D.D. (2016) Relation of transverse compression properties and the degree of brown rot biodeterioration of Pinus glabra in the soil block test. Holzforschung 70 : 1067-1071.

Kartal, S.N., Terzi, E., Yilmaz, H., Goodell, B. (2015) Bioremediation and decay of wood treated with ACQ, micronized ACQ, nano$\mathrm{CuO}$ and CCA wood preservatives. Int. Biodeterior. Biodegrad. 99:95-101.

Kües, U., Mai, C., Militz, H. (2007) “Biological wood protection“. In: Wood Production, Wood Technology, and Biotechnological Impacts. Ed. Kües, U. Universitätsverlag Göttingen, Göttingen. pp. 273-288.

Leithoff, H., Stephan, I., Lenz, M.T., Peek, R.D. (1995) Growth of copper tolerant brown rot fungus Antrodia vaillantii on different substrates. International Research Group on Wood Protection, IRG/WP 95-10121.

Little, N.S., Schultz, T.P., Nicholas, D.D. (2010) Effect of different soils and $\mathrm{pH}$ amendments on brown-rot decay activity in a soil block test. Holzforschung 64:667-671.

Lombard, F.F., Chamuris, G.P. (1990) Basidiomycetes. In: Identification Manual for Fungi from Utility Poles in the Eastern United States. Eds. Wang, C.J.K., Zabel, R.A. Allen Press, Lawrence, Kansas. pp. 21-104.

Mai, C., Militz, H. (2007) Chemical wood protection. In: Wood Production, Wood Technology, and Biotechnological Impacts. Ed. Kües, U. Universitätsverlag Göttingen, Göttingen. pp. 259-271.

Nobles, M.K. (1965) Identification of cultures of wood inhabiting hymenomycetes. Can. J. Bot. 43:1097-1139.

Palfreyman, J.W., Bruce, A. (1994) "Detection and biocontrol of wood decay organisms“. In: Building Mycology. Ed. Singh, J. Chapman \& Hall, UK. pp. 170-191.
Pfeffer, A., Hoegger, P.J., Kües, U., Militz H. (2012) Fungal colonization of outside weathered modified wood. Wood Sci. Technol. 46:63-72.

Quitt, H. (2009) Holzschutzmittelverzeichnis: Verzeichnis der Holzschutzmittel mit allgemeiner bauaufsichtlicher Zulassung, Auflistung der Holzschutzmittel mit RAL-Gütezeichen, Auflistung der Bläueschutzmittel nach VdL-Richtlinie. In: Schriften des Deutschen Instituts für Bautechnik. Ed. Schmidt, E. Berlin, Germany. pp. 74-75.

Ringman, R., Pilgård, A., Brischke, C., Richter, K. (2014) Mode of action of brown rot decay resistance in modified wood: a review. Holzforschung 68:239-246.

Schimdt, O., Kebernik, U. (1989) Characterization and identification of the dry rot fungus Serpula lacrymans by polyacrylamide gel electrophoresis. Holzforschung 43:195-198.

Schmidt, O., Moreth, U. (1996) Biological characterization of Poria indoor brown-rot fungi. Holzforschung 50:105-110.

Schmidt, O., Moreth, U. (2003) Molecular identity of species and isolates of internal pore fungi Antrodia spp. and Oligoporus placenta. Holzforschung 57:12-126.

Schubert, M., Fink, S., Schwarze, F.W.M.R. (2008) In Vitro Screening of an antagonistic Trichoderma strain against wood decay fungi. Arboric. J. 31:227-248.

Schultz, T.P., Nicholas, D.D. (2010) A proposed accelerated field stake test for rapid assessment of wood preservative systems. Holzforschung 64:673-679.

Schultz, T.P., Nicholas, D.D. (2012) Relative fungal efficacy results from the soil block test with a long incubation period of three commercial copper wood preservatives. Holzforschung 66:245-250.

Schwarze, F.W.M.R. (2007) Wood decay under the microscope. Fungal Biol Rev. 21:133-170.

Schwarze, F.W.M.R., Jauss, F., Spenser, C., Hallam, C., Schubert, M. (2012) Evaluation an antagonistic Trichoderma strain for reducing the rate of wood decomposition by the white rot fungus Phellinus noxius. Biol. Control. 61:160-168.

Sieber, T.N. (1995) Pynrenochaeta ligni-putridi spp. nov., a new coelomycete associated with butt rot of Picea abies in Switzerland. Mycol. Res. 99:274-276.

Sierra-Alvarez, R. (2007) Fungal bioleaching of metals in preservativetreated wood. Process Biochem. 42:798-804.

Stalpers, J.A. (1978) Identification of Wood-inhabiting Aphyllophorales in Pure Culture. Centraalbureau voor Schimmelcultures, Baarn.

Theden, G., Kottlors, C. (1965) Verfahren zum Sichtbarmachen von Schutzmitteln im Holz. Mitteilungen der Gesellschaft für Holzforschung. Bundesanstalt für Materialprüfung, Berlin-Dahlem, Germany. pp. 36-66.

White, T.J., Bruns, T., Lee, S. and Taylor, J. (1990) Amplification and direct sequencing of fungal ribosomal RNA genes for phylogenetics. In: PCR Protocols: a Guide to Methods and Applications. Eds. Innis, M.A., Gelfand, D.H., Sninsky, J.J., White, T.J. Academic Press: San Diego, U.S.A. pp. 315-322.

Wilcox, W.W., Dietz, M. (1997) Fungi causing above ground wood decay in structures in California. Wood Fiber Sci. 29:291-298.

Woodward, B. and De Groot, R. (1999) Tolerance of Wolfiporia cocos isolates to copper in agar media. Forest Prod. J. 49:87-94.

Young, G.Y. (1961) Copper tolerance of some wood rotting fungi. Report no. 2223 U.S. Department of Agriculture, Forest Service, Forest Products Laboratory, Madison, WI.

Zabel, R.A., Lombard, F.F., Wang, C.J.K., Terracina F.C. (1985) Fungi associated with decay in treated southern pine utility poles in the eastern United States. Wood Fiber Sci. 17:75-91. 